al-Kimiya, Vol. 6, No. 1 (1-8) Juni 2019/Syawwal 1440 H

\title{
BRIKET ARANG TEMPURUNG KAWISTA (Limonia acidissima) TERAKTIVASI NAOH DENGAN PEREKAT ALAMI
}

\author{
ENY YULIANTI ${ }^{1}$, RAUdATUl JANNAH ${ }^{1}$, LILIK MIFTAHUL KHOIROH ${ }^{1}$, DAN VINA NURUL ISTIGHFARINI ${ }^{1}$ \\ ${ }^{1}$ Jurusan Kimia, Fakultas Sains dan Teknologi, UIN Maulana Malik Ibrahim Malang \\ Jl. Gajayana No.50, Dinoyo Kec. Lowokwaru Kota Malang \\ *alamat email korespondensi: enyyulianti@kim.uin-malang.ac.id
}

\begin{tabular}{l} 
Informasi Artikel \\
\hline Riwayat Naskah : \\
Diterima pada 31 \\
Mei 2019 \\
Diterima setelah \\
direvisi pada 4 Juli \\
2919 \\
Diterbitkan pada 5 \\
Juli 2019
\end{tabular}

Juli 2019

\begin{abstract}
Abstrak/Abstract
Penelitian tentang pemanfaatan tempurung tempurung kawista (Limonia acidissima) telah dilakukan sebagai bahan dasar pembuatan briket arang. Variabel jenis perekat alami berupa gel yang terbuat dari tepung beras, tepung ketan, dan tepung tapioka. Selanjutnya jenis perekat alami terbaik ditentukan, yang mampu menghasilkan nilai kalor tertinggi dan kualitas briket tempurung kawista sesuai dengan SNI. Metode perlakuan terhadap tempurung kawista meliputi aktivasi $\mathrm{NaOH} 0,1 \mathrm{M}$, karbonisasi, pencetakan dan pengepresan. Karakterisasi briket arang dilakukan melalui uji mutu SNI, termasuk penentuan nilai kalor tertinggi, serta identifikasi gugus fungsi sampel kulit, arang kulit, dan briket arang menggunakan spektrofotometer FTIR. Hasil penelitian menunjukkan bahwa perlakuan aktivasi meningkatkan kualitas briket arang. Penggunaan semua jenis perekat dengan perbandingan massa arang : perekat sebesar $9: 1$, menghasilkan briket arang yang memenuhi kualitas SNI. Nilai kalor tertinggi sebesar $6905 \mathrm{kal} / \mathrm{g}$ terdapat pada sampel briket arang tempurung kawista teraktivasi dengan jenis perekat alami gel tepung beras. Melalui penentuan mutu briket arang terbaik sesuai standar SNI, diperoleh nilai kadar air 3,733\%, kadar zat menguap $8,014 \%$, kadar abu 2,373\%, dan kadar C terikat $85,88 \%$. Secara garis besar, keseluruhan gugus fungsi yang teridentifikasi hampir sama yaitu meliputi gugus $\mathrm{O}-\mathrm{H}$ pada $3500-3400 \mathrm{~cm}^{-1}, \mathrm{C}=\mathrm{C}$ pada $1650-1600 \mathrm{~cm}^{-1}, \mathrm{C}-\mathrm{H}$ pada $1384-1383 \mathrm{~cm}^{-1}$, dan $\mathrm{C}-\mathrm{OH}$ pada daerah $1047-1034 \mathrm{~cm}^{-1}$. Perbedaan yang nampak adalah briket arang yang teraktivasi memiliki intensitas yang lebih tinggi dibandingkan dengan briket tanpa aktivasi
\end{abstract}

Research has been carried out on the utilization of the Kawista shell (Limonia acidissima) as the basic material for making charcoal briquettes. Variable types of natural adhesive in the form of gel made from rice flour, sticky rice flour, and tapioca flour. Furthermore, the best type of natural adhesive is determined, which can produce the highest calorific value and quality of kawista shell briquettes according to SNI. The treatment method for the kawista shell includes $0.1 \mathrm{M} \mathrm{NaOH}$ activation, carbonization, printing, and pressing. Charcoal briquette characterization was investigated through SNI quality test, including determination of the highest calorific value and identification of functional groups of the samples of the skin, charcoal, and charcoal briquettes using FTIR spectrophotometer. The results showed that the activation treatment improved the quality of the charcoal briquettes. The use of all types of adhesives with a ratio of char mass: adhesive of $9: 1$, producing charcoal briquettes that meet SNI quality. The highest calorific value of $6905 \mathrm{cal} / \mathrm{g}$ was found in the activated coconut shell charcoal briquettes with the type of the natural rice gel adhesive. Determination of the best quality of charcoal briquettes according to SNI standards was obtained by the value of $3.733 \%$ moisture, $8.014 \%$ evaporating substance, $2.337 \%$ ash content, and $85.88 \% \mathrm{C}$ bound. In outline, the whole functional group identified is almost the same, which includes the O-H group at $3500-3400 \mathrm{~cm}^{-1}, C=C$ at $1650-1600 \mathrm{~cm}^{-1}, \mathrm{C}-\mathrm{H}$ at 1384-1383 $\mathrm{cm}^{-1}$, and $\mathrm{C}-\mathrm{OH}$ at area $1047-1034 \mathrm{~cm}^{-1}$. The apparent difference is activated briquettes has a higher intensity than briquettes without activation.

\section{PENDAHULUAN}

Briket mulai digunakan secara luas sebagai bahan bakar terbarukan, baik di industri maupun rumah tangga, karena beberapa kelebihannya yaitu mempunyai energi dan kuat tekan yang tinggi, hemat dan praktis, serta menghasilkan bahan bakar yang bersih. Dengan membuat briket, kepadatan biomassa dapat ditingkatkan dari 40 hingga 200 $\mathrm{kg} / \mathrm{m}^{3}$ menjadi $600-1200 \mathrm{~kg} / \mathrm{m}^{3}$ yang akan mengurangi kebutuhan ruang penyimpanan secara signifikan [1].

Kawista merupakan tanaman buah tropis yang termasuk dalam suku jeruk-jerukan (Rutaceae). Di Indonesia, tanaman ini tersebar di Pulau Sumatera, Jawa, Bali, dan Nusa Tenggara. 
Buah Kawista berbentuk bulat dengan kulit tebal dan keras serta beraroma khas [2]. Pemanfaatannya di antaranya digunakan sebagai obat dan minuman. Namun, umumnya kulit buahnya tidak termanfaatkan [3]. Salah satu pemanfaatan limbah kulit buah kawista yaitu dapat diolah menjadi bahan bakar padat alternatif berupa briket.

Briket yang baik adalah briket yang memenuhi standar mutu agar dapat digunakan sesuai keperluannya. Mutu briket sesuai SNI No. $1 / 6235 / 2000$ yaitu memiliki kadar air $\leq 8 \%$, kadar abu $\leq 8 \%$, kandungan karbon $\geq 77 \%$, serta nilai kalor sebesar $\geq 5500 \mathrm{kal} / \mathrm{g}$. Kandungan abu yang tinggi dapat menurunkan nilai kalor briket sehingga kualitas briket semakin rendah [4]. Semakin besar nilai kalorinya maka semakin banyak energi termal yang dihasilkan oleh pembakarannya [5]. Tempurung kawista sangat berpotensi sebagai karbon aktif [3]. Kadar karbonnya sekitar $65,1 \%$, sehingga sangat berpotensi sebagai bahan pembuat briket arang yang baik [6].

Proses aktivasi dapat mengubah sifat fisika dan kimia. Aktivasi dapat memecah ikatan hidrokarbon dengan cara mengoksidasi molekulmolekul permukaan. Hal ini sangat diperlukan untuk memperbesar luas permukaan pori arang [7].

Suhu optimum karbonisasi briket campuran buah bintaro dan tempurung kelapa adalah $400^{\circ} \mathrm{C}$ [8]. Berdasarkan kekerasannya, tempurung kelapa memiliki banyak kesamaan dengan tempurung kawista.

Pembuatan briket dengan penambahan bahan perekat yang tepat akan menjadikan briket arang menjadi lebih kuat dari tekanan luar, mampu meningkatkan nilai bakar dari briket arang tersebut [9], serta menjadikan briket tidak mudah pecah [10]. Oleh karena itu, dibutuhkan pemilihan perekat yang tepat dalam produksi briket bahan bakar untuk mendapatkan kinerja optimal, hasil tinggi, dan konten energi.

Sebagai polimer organik alami, pati adalah perekat alami yang ideal. Secara umum, sekitar 4$8 \%$ pati diperlukan untuk membuat briket. Sumber pati dapat berupa tepung jagung, tepung gandum, tepung terigu, tepung beras, tepung singkong, tepung kentang, dan lain-lain [11]. Pada riset yang dikembangkan oleh Olugbade dan Mohammed [10] menunjukkan bahwa briket dari dedak padi dan tempurung kelapa sawit dengan perekat alami pati singkong memiliki nilai kalor dan kuat tekan yang lebih tinggi. Partikel halus dan kecil dapat meningkatkan kepadatan dan kandungan energi per satuan volume briket.

Berbagai jenis briket membutuhkan pengikat briket yang berbeda. Perekat organik mempunyai kelebihan dibandingkan dengan perekat anorganik seperti semen, bentonit dan kalsium oksida, karena memiliki ikatan yang baik, kinerja pembakaran yang baik, dan abu yang rendah [11]. Pada penelitian ini digunakan variasi jenis perekat alami yaitu gel tepung beras, ketan, dan tapioka dengan komposisi perbandingan campuran arang dan perekat sebesar 9:1. Pemilihan jenis perekat ini didasarkan pada kandungan amilopektin dalam ketiga jenis perekat tersebut, yang bersifat lebih lengket dan memiliki daya ikat yang baik. Hal ini sangatlah penting, sehingga diharapkan briket yang dihasilkan tidak mudah retak.

Uji kuliatas briket meliputi kadar air, kadar abu, kadar karbon dan nilai kalor. Semakin tinggi nilai, semakin tinggi juga kualitas briket arang. Nilai kalor ditentukan oleh kadar air, kadar abu dan kadar karbon. Jika nilai kadar air dan kadar abu tinggi maka nilai kalornya akan rendah, tetapi jika kadar karbon tinggi maka akan menaikkan nilai kalor [12].

\section{EKSPERIMEN}

\section{Material}

Bahan yang digunakan pada penelitian ini adalah tempurung buah kawista (Limonia acidissima), tepung beras, tepung ketan, tepung tapioka (merek sama yaitu Rose Brand), aquades, asam benzoat, indikator metil merah, larutan standar $\mathrm{Na}_{2} \mathrm{CO}_{3} 0,0725 \mathrm{~N}$ dan larutan $\mathrm{NaOH} \quad 0,1$ N.

\section{Instrumentasi}

Alat yang digunakan pada penelitian ini adalah alumunium foil, ayakan 100 mesh, Bomb calorimeter (Parr), cawan porselen atau penguap, cawan crucible, cetakan silinder (d: $13 \mathrm{~mm})$, hot plate, loyang, mortar alu, neraca analitik, oven listrik, pengepres hidrolik (Carver), penjepit kayu, peralatan gelas, $\mathrm{pH}$ universal, spatula, Transform Infrared Spectroscopy (FTIR) merek Varian, stopwatch, termometer, dan tanur listrik merek Thermo Scientific.

\section{Prosedur}

\section{Persiapan Bahan Baku}

Prosedur periapan bahan baku mengacu pada penelitian (Suryani, 2012) [8]. Tempurung buah kawista yang tua dibersihkan menggunakan air, kemudian dikeringkan dalam oven pada $105^{\circ} \mathrm{C}$ selama 60 menit hingga diperoleh berat konstan. Selanjutnya tempurung buah kawista dihancurkan dan siap untuk diaktivasi kimia menggunakan 
$\mathrm{NaOH} 0,1 \mathrm{~N}$ [10] modifikasi).

Perekat gel dibuat dari masing-masing jenis tepung dengan perbandingan campuran bubuk arang dan perekat sebesar 9:1 dan dilarutkan kedalam air hangat secukupnya. Selanjutnya larutan tepung tersebut dipanaskan di atas hot plate, sambil diaduk dan ditambah aquades hingga pati dari tepung tersebut akan berbentuk gel dan lengket [8]

Aktivasi menggunakan larutan $\mathrm{NaOH} \quad 0,1$ $\mathrm{N}$ dilakukan pada sampel tempurung kawista sebelum diarangkan. Perendaman $50 \mathrm{~g}$ sampel ke dalam $100 \mathrm{~mL}$ aktivator $\mathrm{NaOH} 0,1 \mathrm{~N}$ dilakukan selama 30 menit, lalu ditiriskan ( \pm 24 jam), kemudian dioven pada suhu $105^{\circ} \mathrm{C}$ selama $\quad 60$ menit hingga diperoleh berat konstan. Selanjutnya sampel yang telah kering dikarbonisasi pada suhu $400^{\circ} \mathrm{C}$ selama 60 menit [8]. Arang yang dihasilkan dicuci menggunakan aquades sampai bersifat netral dan ditiriskan, kemudian dikeringkan kembali dalam oven pada suhu $105^{\circ} \mathrm{C}$ selama 1 jam.

\section{Pembuatan Briket Arang}

Arang kering dihaluskan dan diayak menggunakan ayakan 100 mesh. Selanjutnya dicampur dengan masing-masing perekat alami berupa gel tepung (beras, ketan, tapioka) yang sudah siap, sampai benar-benar merata dengan perbandingan campuran bubuk arang dan perekat sebesar 9:1 (berat total $1 \mathrm{~g}$ ). Selanjutnya dicetak pada cetakan silinder (d: $13 \mathrm{~mm}$ ), ditekan menggunakan pengepres hidrolik dengan tekanan 0,5 ton selama 5 menit, selanjutnya dipanaskan kembali di oven pada suhu $105^{\circ} \mathrm{C}$ selama 5 jam agar diperoleh briket arang kering. Semua perlakuan tersebut diulangi untuk pembuatan briket arang tempurung kawista tanpa teraktivasi $\mathrm{NaOH}$ $0,1 \mathrm{~N}[8]$.

\section{Pengukuran Nilai Kalor Terbaik Briket}

Pengukuran dilakukan dengan menggunakan alat kalorimeter bom dengan metode mengacu pada penelitian sebelumnya [13]. Cara ini meliputi 2 langkah yaitu penentuan kapasitas kalor kalorimeter yang dilanjutkan penentuan kalor pembakaran briket arang. Pada penentuan kapasitas calorimeter, senyawa yang digunakan sebagai standar yaitu asam benzoate 1 gram. Selanjutnya alat ditutup rapat, kemudian diisi gas oksigen sampai tekanan menunjukkan 20 atm.

Tabung kalorimeter diisi $2 \mathrm{~L}$ air. temperatur di dalam tabung diatur $\pm 1,5^{\circ} \mathrm{C}$ di bawah suhu ruang. Selanjutnya tabung ini dimasukkan ke dalam kalorimeter, kemudian alat bom dimasukkan ke dalam tabung yang dilengkapi dengan termometer dan ditunggu sekitar 4 sampai 5 menit agar suhu mantel sama dengan suhu air di dalam tabung. Temperatur air di dalam tabung dicatat $\left(\mathrm{T}_{1}\right)$ dan arus listrik dijalankan untuk membakar cuplikan. Suhu air dalam tabung akan naik setelah 20 detik.. Kenaikan suhu air tiap menit dicatat hingga dicapai suhu tertinggi yang tetap selama 2 menit dan suhu tertinggi ini $\left(\mathrm{T}_{2}\right)$ dicatat.

Tahap berikutnya adalah, kalorimeter dibuka dan alat bom dikeluarkan dari tabung. Drei diputar agar gas hasil reaksi dapat keluar. Bagian dalam alat bom dibilas air dan ditampung cairan hasil bilasan dalam erlenmeyer. Selanjutnya, cairan ini dititrasi dengan $\mathrm{Na}_{2} \mathrm{CO}_{3} 0,0725 \mathrm{~N}$ dan ditambahkan metil merah sebagai indikator. Titrasi dihentikan saat munculnya warna coklat bening kekuningan. Prosedur tersebut diulangi untuk pengukuran pada sampel briket arang [13]. Nilai kalor dihitung dengan menggunakan persamaan (1).

$$
Q=\frac{\Delta T . W-e 1-e 2}{m}
$$

dengan $W$ adalah kesetaraan energi $\left(2426 \mathrm{kal} /{ }^{\circ} \mathrm{C}\right)$ asam benzoat, $m$ adalah massa sampel briket (gram), $e_{l}$ adalah koreksi panas titrasi asam nitrat, $e_{2}$ adalah koreksi panas kawat pembakar dan $\Delta T$ adalah kenaikan temperatur koreksi $\mathrm{T}_{2}-\mathrm{T}_{1}$ [13]. Nilai kesetaraan energi $W$ dihitung dengan persamaan (2).

$$
W=\frac{H \cdot m+e 1+e 2}{\Delta T}
$$

dengan $H$ adalah panas pembakaran standar asam benzoat $(6318 \mathrm{kal} / \mathrm{g}), m$ adalah massa asam benzoat $(1,1651 \mathrm{~g}), \quad e_{1}$ adalah koreksi panas pembentukan asam nitrat $(1 \mathrm{kal} / \mathrm{mL}), e_{2}$ adalah koreksi panas kawat pembakar $(2,3 \mathrm{kal} / \mathrm{cm})$ dan $\Delta T$ adalah kenaikan suhu selama pembakaran asam benzoat yaitu sebesar $3,047^{\circ} \mathrm{C}$.

\section{Pengukuran Kadar Air}

Sebanyak $1 \mathrm{~g}$ sampel briket diletakkan dalam cawan penguap lalu dipanaskan dalam oven pada suhu $105^{\circ} \mathrm{C}$ selama 1 jam. Selanjutnya didinginkan pada desikator dan ditimbang hingga beratnya konstan. Kadar air (\%) dihitung dengan persamaan (3) [14].

$$
\frac{A-B}{A} \times 100 \%
$$


A : sampel awal tanpa cawan penguap (g)

B : sampel setelah dipanaskan pada $105^{\circ} \mathrm{C}(\mathrm{g})$

\section{Pengukuran Kadar Zat Menguap}

Pengukuran kadar zat menguap dilakukan sesuai prosedur pada penelitian sebelumnya [14]. Cawan crucible dipanaskan dalam oven pada suhu $90^{\circ} \mathrm{C}$ selama $1 \mathrm{jam}$, didinginkan dalam desikator kemudian ditimbang hingga beratnya konstan. Selanjutnya cawan diisi dengan sampel sebanyak 1 g, dipanaskan dalam oven pada suhu $80-85^{\circ} \mathrm{C}$ selama 1 jam, didinginkan pada desikator, dan ditimbang hingga beratnya konstan. Kadar zat menguap (\%) dihitung dengan persamaan (4).

$$
\frac{\mathrm{A}-\mathrm{C}}{\mathrm{A}} \times 100 \%
$$

A : sampel awal tanpa cawan crucible (g)

$\mathrm{C}$ : sampel setelah dioven pada $80-85^{\circ} \mathrm{C}(\mathrm{g})$

\section{Pengukuran Kadar Abu}

Pengukuran kadar abu dilakuakn sesuai prosedur pada penelitian sebelumnya [14]. Cawan crucible ditimbang tanpa tutupnya, kemudian diisi dengan sampel sebanyak $1 \mathrm{~g}$, dimasukkan dalam tanur dan dipanaskan pada suhu $500^{\circ} \mathrm{C}$ selama 30 menit, kemudian dilanjutkan pemanasan pada suhu $825^{\circ} \mathrm{C}$ selama 30 menit. Crucible dipindahkan dari tanur, didinginkan dalam desikator, dan ditimbang segera. Kadar abu (\%) dihitung dengan persamaan (5).

$$
\frac{\mathrm{D}-\mathrm{E}}{\mathrm{A}} \times 100 \%
$$
A : sampel awal tanpa cawan crucible (g)
$\mathrm{D}:$ berat cawan $+\mathrm{abu}(\mathrm{g})$
$\mathrm{E}$ : berat cawan kosong $(\mathrm{g})$

\section{Pengukuran Kadar Karbon C Terikat}

Pengukuran Kadar Karbon terikat dilakukan sesuai dengan prosedur pada penelitian sebelumnya [14]._Karbon terikat adalah fraksi karbon (C) dalam briket, selain fraksi air, zat menguap, dan abu. Kadar karbon terikat (\%) dihitung menggunakan persamaan (6).

$$
(\%)=100-(\mathrm{M}+\mathrm{V}+\mathrm{A}) \%
$$

\footnotetext{
M (moisture) : kadar air (\%)

$\mathrm{V}$ (volatile matter) : kadar zat menguap (\%)

A (ash) : kadar abu (\%)
}

\section{Uji Gugus Fungsi dengan Menggunakan} Spektrofotometer FTIR

Identifikasi gugus fungsi pada sampel kulit kawista, arang kulit, dan briket arang dengan menggunakan spektrofotometer FTIR. Uji ini digunakan untuk mengetahui perbedaan gugus fungsi pada masing-masing sampel yang berbeda. Sebanyak $10 \mathrm{mg}$ sampel digerus dengan $20 \mathrm{mg} \mathrm{KBr}$ dalam keadaan bebas air dan dibuat lempeng $\mathrm{KBr}$, lalu lempeng/pelet $\mathrm{KBr}$ yang terbentuk diukur serapannya dengan spektrofotometer FTIR.

\section{HASIL DAN PEMBAHASAN}

Briket dari arang tempurung buah kawista teraktivasi dan tanpa teraktivasi $\mathrm{NaOH}$ menggunakan bahan perekat tepung beras, tepung ketan, dan tepung tapioka dicetak berbentuk silinder dengan menggunakan pres hidrolik sebagaimana Gambar 1 dan Gambar 2. Aktivasi menggunakan $\mathrm{NaOH}$ bertujuan untuk membuka pori-pori karbon yang masih tertutup oleh senyawaan organik, seperti lignin dan hemiselulosa.

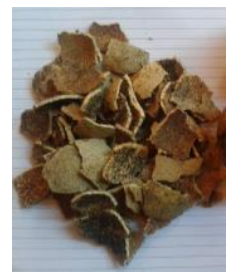

(a)

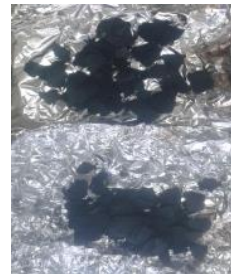

(b)

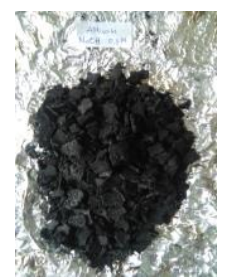

(c)
Gambar 1. (a) Tempurung kawista; (b) arang tempurung kawista tanpa aktivasi; (c) arang tempurung kawista teraktivasi $\mathrm{NaOH} 0,1 \mathrm{~N}$.

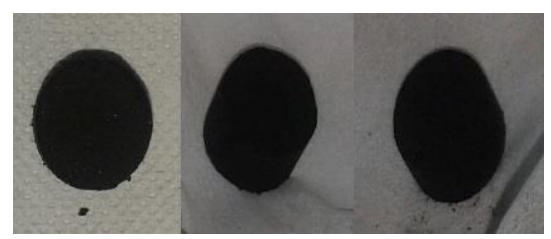

a

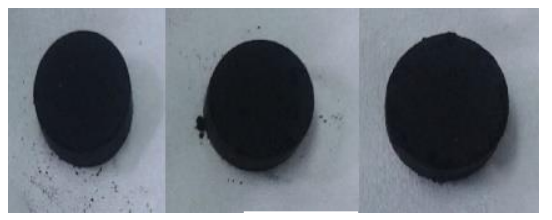

b

Gambar 2. (a) Briket hasil pembuatan tanpa aktivasi; (b) briket hasil pembuatan menggunakan aktivasi $\mathrm{NaOH}$ 


\section{Kadar Air}

Data kadar air dari semua jenis sampel briket tempurung kawista dengan maupun tanpa perlakuan aktivasi kimia dapat dilihat pada Gambar 3. Hasilnya menunjukkan nilai yang relatif rendah, yaitu $<5 \%$. Semakin rendah kadar air pada briket maka briket semakin berkualitas [10]. Briket dengan perekat tepung beras memiliki kadar air paling rendah dibandingkan dengan yang lain, sedangkan briket yang dihasilkan tanpa aktivasi memiliki nilai kalor yang lebih rendah dibandingkan dengan briket dengan aktivasi $\mathrm{NaOH}$. Saat proses aktivasi (yaitu proses sebelum karbonasi), dimungkinkan tempurung kawista mengalami delignifikasi dan kandungan selulosa yang masih tersisa pada tempurung kawista mengalami swelling yang dapat mudah mengikat air. Hal ini dikarenakan tempurung buah kawista merupakan bahan alam yang mengandung senyawaan polimer.

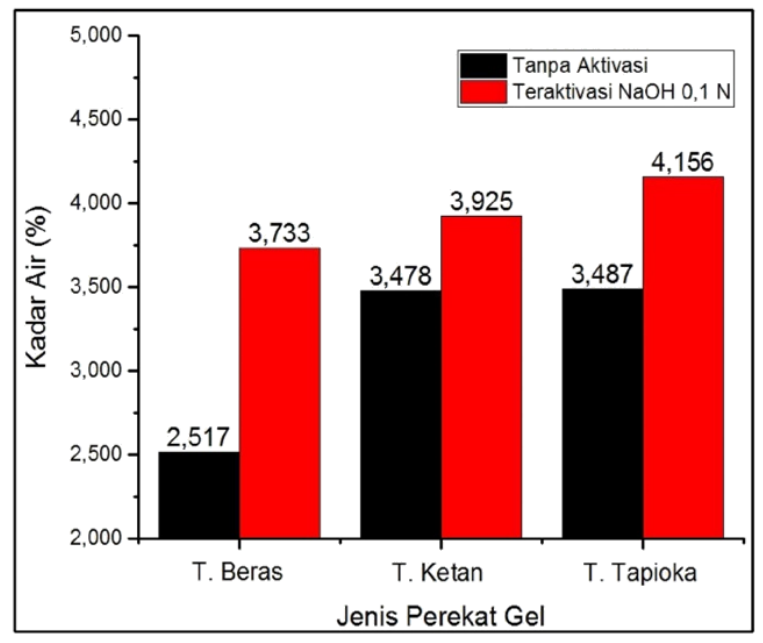

Gambar 3. Grafik kadar air briket tempurung buah kawista

\section{Kadar Zat Menguap}

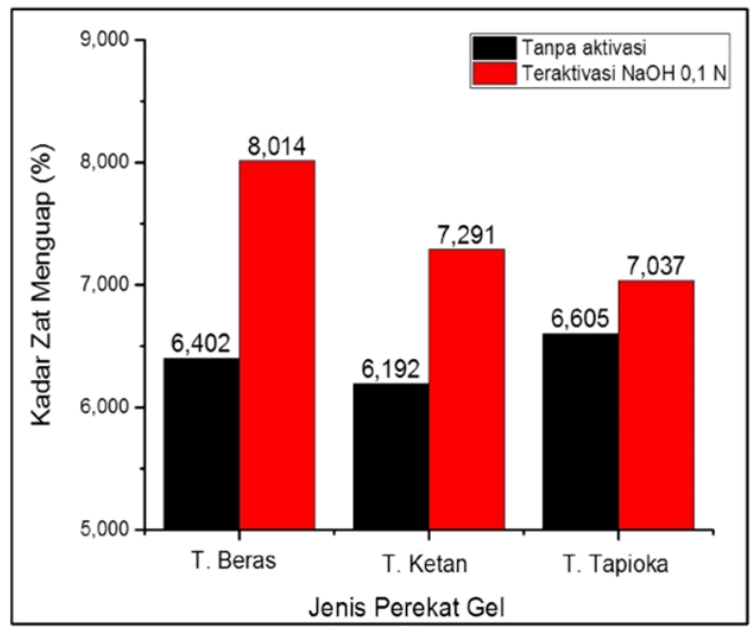

Gambar 4. Grafik kadar zat menguap briket arang
Data kadar menguap briket arang dengan maupun tanpa perlakuan aktivasi kimia dapat dilihat pada Gambar 4. Kadar zat menguap pada briket tertinggi dihasilkan pada briket menggunakan aktivasi $\mathrm{NaOH}$ dengan perekat tepung beras. Kadar zat menguap masih sesuai standar SNI $(\leq 16,14 \%) \quad$ [9]. Tingginya kadar zat menguap ini dimungkinkan karena pengaruh perekat yang ditambahkan. Tepung beras mengandung kadar amilosa cukup tinggi dibandingkan tepung ketan dan tepung tapioka, yaitu sebesar 25\% [15].

\section{Kadar Abu}

Data kadar abu briket tempurung buah kawista dengan maupun tanpa perlakuan aktivasi kimia dapat dilihat pada Gambar 5. Menurut tandar mutu SNI bahwa briket yang baik memiliki kadar abu sebesar $\leq 5,51 \%$ [1]. Kadar abu briket tanpa aktivasi lebih tinggi dibandingkan dengan briket teraktivasi $\mathrm{NaOH}$, hal ini dikarenakan dengan adanya aktivasi $\mathrm{NaOH}$, kandungan lignin dan hemiselulosa yang ada dalam tempurung buah kawista sebagian hilang, sehingga menyebabkan kadar abu yang dihasilkan lebih rendah. Kadar abu pada briket dengan aktivasi $\mathrm{NaOH}$ tertinggi adalah pada briket dengan menggunakan tepung beras, hal ini dikarenakan pada tepung beras kandungan senyawa amilosa lebih banyak dari pada yang lain. Semakin banyak kandungan senyawaan organik yang ada dalam briket menyebabkan turunnya kadar abu [10].

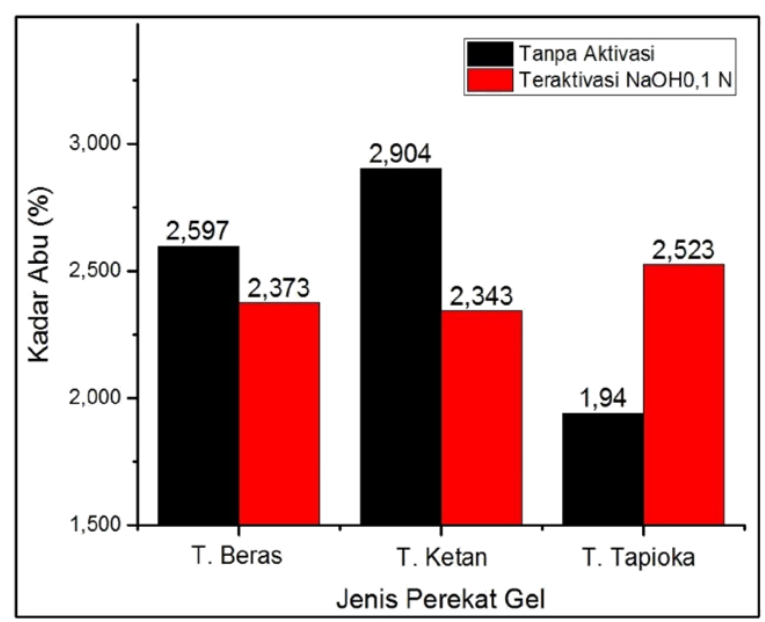

Gambar 5. Grafik kadar abu briket tempurung buah kawista

Pengaruh keberadaan abu yang berlebih pada arang menyebabkan penyumbatan pada poripori arang sehingga luas permukaan arang menjadi berkurang. Pori-pori yang tersumbat inilah yang akan berakibat pada turunnya nilai kalor briket arang tersebut. 


\section{Kadar Karbon Terikat}

Data kadar karbon terikat briket tempurung buah kawista dengan maupun tanpa perlakuan aktivasi kimia dapat dilihat pada Gambar 6. Semakin besar senyawaan organik yang terdapat pada briket, menghasilkan kadar karbon terikat yang juga besar. Kadar karbon terikat pada briket dengan aktivasi lebih rendah dibandingkan pada briket tanpa aktivasi. Hal karena pada proses aktivasi $\mathrm{NaOH}$ terjadi proses delignifikasi yang akan menghilangkan sebagian polimer organik yaitu lignin sehingga menyebabkan penurunan kadar karbon terikat.

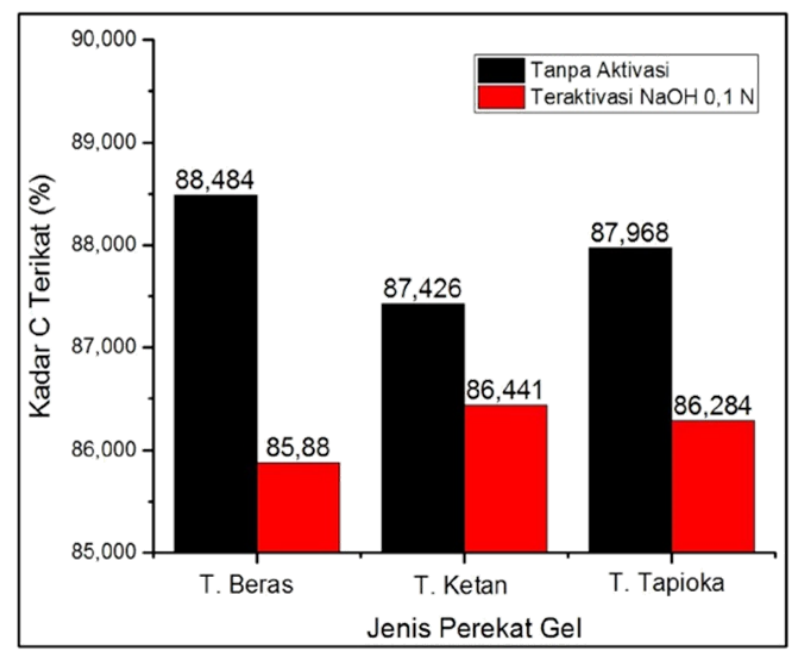

Gambar 6. Grafik kadar karbon terikat

\section{Nilai Kalor Briket}

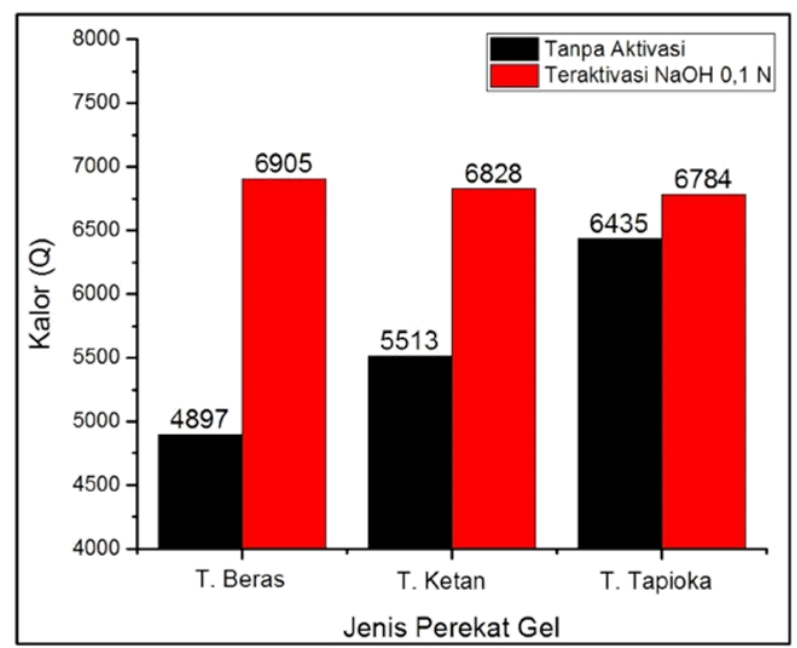

Gambar 7. Grafik nilai kalor briket tempurung buah kawista

Data nilai briket tempurung buah kawista dengan maupun tanpa perlakuan aktivasi kimia dapat dilihat pada Gambar 7. Nilai kalor briket tempurung buah kawista dengan atau tanpa aktivasi $\mathrm{NaOH}$ memiliki perbedaan nilai kalor yang signifikan. Briket dengan perlakuan aktivasi memiliki nilai kalor yang sangat besar dibandingkan dengan tanpa aktivasi. Nilai kalor tertinggi terdapat pada briket teraktivasi $\mathrm{NaOH}$ dengan menggunakan perekat tepung beras, yaitu sebesar $6905 \mathrm{kal} / \mathrm{g}$. Menurunnya nilai kalor pada briket salah satunya dipengaruhi oleh kandungan kadar air yang cukup tinggi.

\section{Analisis Gugus Fungsi Kulit, Arang, dan Briket Tempurung Buah Kawista}

Berdasarkan spektra FTIR pada Gambar 8 bahwa terjadi perubahan struktur senyawa yang terkandung pada masing-masing sampel. Tempurung atau kulit kawista sebagian besar mengandung selulosa $39,54 \%$, hemiselulosa $26,06 \%$ dan lignin 29,86\% [16]. Perubahan kandungan senyawa akan terjadi setelah dilakukan karbonisasi menjadi sampel arang (bukan kulit lagi) yaitu sebagian selulosa dan lignin akan diuraikan menjadi tar (hasil pembakaran), kandungan karbon akan naik hingga 98\%, dan sisanya berupa abu. Hal ini ditunjukkan dengan besarnya intensitas gugus $\mathrm{C}=\mathrm{C}$ pada spektra sampel arang dibandingkan dengan intensitas gugus $\mathrm{C}=\mathrm{C}$ pada spektra sampel kulit arang. Komponen volatile dan air akan hilang saat proses karbonisasi.

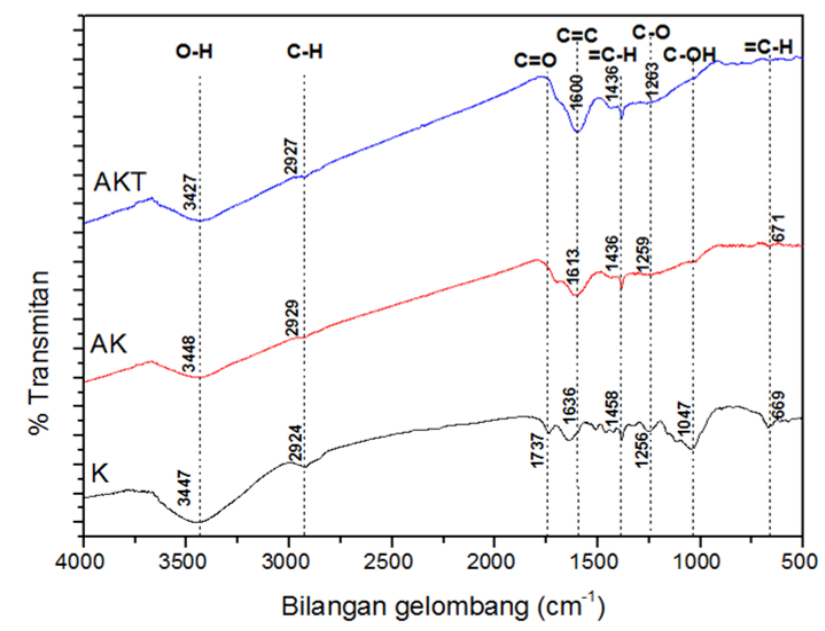

Gambar 8. Spektra FTIR sampel kulit (K), arang kulit (AK), dan arang kulit teraktivasi (AKT)

Perbedaan gugus fungsi terdapat pada sampel kulit kawista yaitu $\mathrm{C}=\mathrm{O}$ dan $\mathrm{C}-\mathrm{OH}$ masing-masing pada bilangan gelombang 1737 dan $1047 \mathrm{~cm}^{-1}$. Hal ini menunjukkan bahwa terjadi adanya perubahan gugus senyawa dari kulit kawista menjadi arang kulit saat dilakukan pembakaran/pengarangan proses karbonisasi dalam tanur. Hasil identifikasi yang sama ditunjukkan oleh penelitian Apriyantono [15], bahwa pada buah kawista terdapat gugus ester dan 
aldehid serta keton yang ditunjukkan oleh munculnya gugus $\mathrm{C}=\mathrm{O}$ dan $\mathrm{C}-\mathrm{OH}$.

Spektra FTIR setelah aktivasi dibandingkan sebelum aktivasi yaitu, menunjukkan adanya peningkatan intensitas gugus $\mathrm{C}=\mathrm{C}$ pada bilangan gelombang

$1600 \mathrm{~cm}^{-1}$. Bentuk pita karakteristik hemiselulosa (1160-1030 $\left.\mathrm{cm}^{-1}\right)$ berubah sedikit ketika diaktivasi menggunakan $\mathrm{NaOH}$. Bentuk pita khas lignin $\left(1520-1330 \mathrm{~cm}^{-1}\right)$ banyak berubah ketika diaktivasi menggunakan $\mathrm{NaOH}$. Intensitas puncak selulosa menjadi lebih kuat setelah dilakukan aktivasi $\mathrm{NaOH}$, hal ini menunjukkan bahwa sebagian besar selulosa tetap berada dalam material tempurung, dan konten selulosa dalam material meningkat yang ditunjukkan dengan naiknya intensitas $\mathrm{C}=\mathrm{C}$.

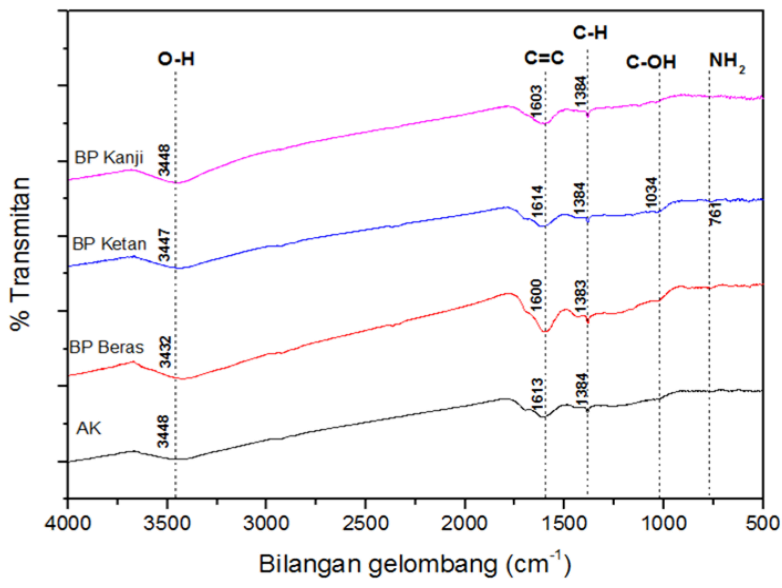

Gambar 9. Spektra FTIR Arang Kulit (murni tanpa aktivasi) dan briket arangnya dengan variasi perekat alami

Gambar 9 menunjukkan bahwa secara keseluruhan spektra menunjukkan gugus fungsi yang sama pada tiap sampel, hanya ada perbedaan gugus pada sampel briket arang dengan perekat gel tepung ketan yaitu $\mathrm{C}-\mathrm{OH}$ dan $\mathrm{NH}_{2}, \quad$ masingmasing pada bilangan gelombang $1034 \mathrm{dan} 761 \mathrm{~cm}^{-}$ ${ }^{1}$. Hal ini menunjukkan bahwa adanya perbedaan gugus senyawa dari perekatnya yaitu tepung ketan. Gugus $\mathrm{NH}_{2}$ (amina) ini dimungkinkan dari kandungan protein pada tepung ketan yang cukup tinggi dibandingkan dengan tepung yang lain. Penyusun utama protein yaitu asam amino yang dihubungkan dengan ikatan peptida dan merupakan senyawa organik komplek berupa makromolekul.

Gambar 10 menunjukkan bahwa antara spektra arang dengan briket terjadi perbedaan intensitas pada gugus $\mathrm{C}=\mathrm{C}$ yang lebih tinggi dibandingkan dengan gugus yang lain. Spektra pada Gambar 9 sama dengan Gambar 10 yang menunjukkan secara keseluruhan gugus fungsi yang teridentifikasi adalah sama pada tiap sampel.
Perbedaannya adalah munculnya gugus $\mathrm{NH}_{2}$ pada sampel briket dengan perekat gel tepung ketan yaitu $\mathrm{NH}_{2}$ pada bilangan gelombang $763 \mathrm{~cm}^{-1}$. Hal ini menunjukkan bahwa adanya perbedaan gugus fungsi senyawa dari perekatnya yaitu tepung ketan. Gugus $\mathrm{NH}_{2}$ (amina) ini dimungkinkan berasal dari kandungan protein pada tepung ketan yang cukup tinggi.

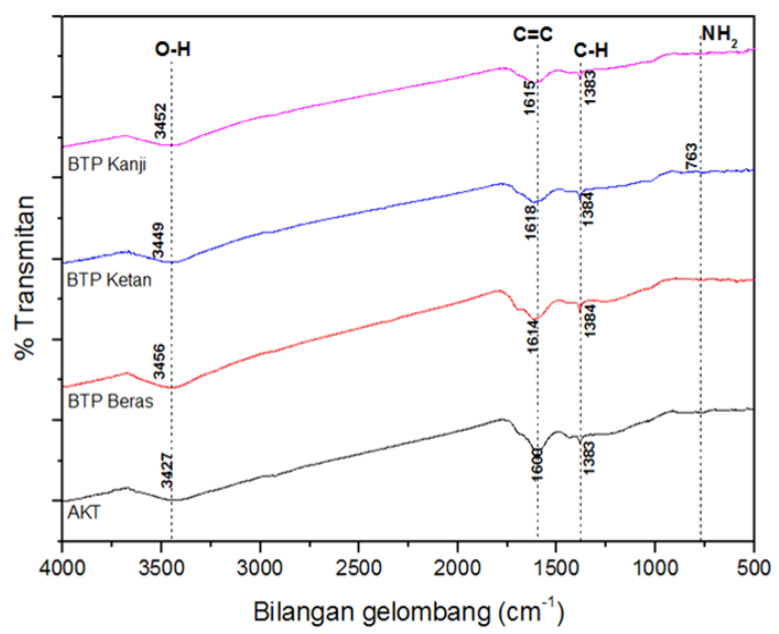

Gambar 10. Spektra FTIR arang kulit teraktivasi $\mathrm{NaOH}$ $0,1 \mathrm{~N}$ dan briket arangnya dengan variasi perekat alami

\section{SIMPULAN}

Tempurung kawista sangat berpotensi untuk dibuat briket arang yang berkualitas. Mutu briket arang tempurung kawista dapat ditingkatkan dengan tambahan perlakuan yaitu dengan mengaktivasinya menggunakan $\mathrm{NaOH} \quad 0,1 \mathrm{~N}$ sebelum dilakukan proses pengarangan. Semua jenis perekat dari tepung beras, ketan, dan tapioka dengan komposisi perbandingan campuran arang dan perekat sebesar 9:1 menghasilkan briket yang memenuhi kualitas SNI No. 1/6235/2000 dengan parameter kadar air, kadar zat menguap, kadar abu, kadar karbon terikat dan nilai kalor. Nilai kalor tertinggi sebesar $6905 \mathrm{kal} / \mathrm{g}$ terdapat pada sampel briket arang tempurung kawista teraktivasi $\mathrm{NaOH}$ $0,1 \mathrm{~N}$ dengan jenis perekat gel tepung beras. Mutu briket arang terbaik diperoleh nilai kadar air $3,733 \%$, kadar zat menguap $8,014 \%$, kadar abu $2,373 \%$, dan kadar C terikat $85,88 \%$. Secara garis besar, keseluruhan gugus fungsi yang teridentifikasi hampir sama yaitu meliputi gugus $\mathrm{O}-\mathrm{H}, \mathrm{C}=\mathrm{C}, \mathrm{C}-\mathrm{H}$, dan $\mathrm{C}-\mathrm{OH}$. Perbedaan yang nampak adalah pada arang yang teraktivasi memiliki intensitas yang lebih tinggi dibanding briket tanpa aktivasi. 


\section{REFERENSI}

[1] S. Mandal, G. V. Prasanna Kumar, T. K. Bhattacharya, H. R. Tanna, dan P. C. Jena, "Briquetting of pine needles (pinus roxburgii) and their physical, handling and combustion properties," Waste Biomass Valorization, p. 1-10, 2018.

[2] N. S. Ariyanti, dan A. Hartana Z. Nurdiana, "Variasi morfologi dan pengelompokan kawista (Limonia acidissima L.) di Jawa dan Kepulauan Sunda Kecil", Floribunda Journal, vol. 5, no. 4, p. 13, 2016.

[3] A. S. Sartape, A. M. Mandare, V. V. Jadhav, P. D. Raut, M. A. Anuse, dan S. S. Kolekar, "Removal of malachite green dye from aqueous solution with adsorption technique using Limonia acidissima (wood apple) shell as low cost adsorbent," Arabian Journal of Chemistry", vol. 10, no. 2, p. s3229-s3238, 2017.

[4] D. Sumangat dan W. Broto, "Kajian teknis dan ekonomis pengolahan briket bungkil biji jarak pagar sebagai bahan bakar tungku," Buletin Teknologi Pascapanen Pertanian, vol. 5, no. 1, 2009.

[5] O. Urbanovičová, K. Krištof, P. Findura, J. Jobbágy, dan M. Angelovič, "Physical and mechanical properties of briquettes produced from energy plants,"., ACTA Universitas Agriculturae Et Silviculturae Mendelianae Brunensis, vol. 65, no. 1, pp. 219-224, 2017.

[6] D. Hendra dan S. Darmawan, "Pembuatan briket arang dari serbuk gergajian kayu dengan penambahan tempurung kelapa," Jurnal Penelitian Hasil Hutan, vol. 18, no. 1, p. 1-9, 2000.

[7] Yulusman, Nasruddin, M. K. Afdhol, A. Amiliana, dan A. Hanafi, "Preparation of activated carbon from palm shells using $\mathrm{KOH}$ and $\mathrm{ZnCl}_{2}$ as the activating agent", IOP Conference Series: Earth and Environmental Science, vol. 75, no. 1, 2017.

[8] I. Suryani, M. Y. Permana U., dan M. H. Dahlan, "Pembuatan briket arang dari campuran buah bintaro dan tempurung kelapa menggunakan perekat amilum," Jurnal Teknik Kimia, vol. 18, no. 1, 2012.
[9] F. Schuchart, K. Wulfert, K. Darmoko, Darmosarkoro, dan W. Sutara, "Pedoman teknis pembuatan briket bioarang". Sumatera Utara. Medan: Balai Penelitian dan Pengembangan Kehutanan, 1996.

[10] T. Olugbade, O. Ojo, dan T. Mohammed, "Influence of binders on combustion properties of biomass briquettes: a recent review", BioEnergy Research, vol. 12, no. 2, pp 241-259, 2019.

[11] G. Zhang, Y. Sun, dan Y. Xu, "Review of briquette binders and briquetting mechanism", Renewable and Sustainable Energy Reviews, vol. 82, no. 1, pp. 477-487, 2018

[12] A. Saleh, I. Novianty, S. Murni, dan A. Nurrahma, "Analisis kualitas briket serbuk gergaji kayu dengan penambahan tempurung kelapa sebagai bahan bakar alternatif", $\mathrm{Al}$ Kimia., vol. 5, no. 1, pp. 21-30, 2017.

[13] O. Nurhilal, S. Setianto, dan A. Suhanda, "Desain kalorimeter bomb biomassa dengan metode oksigen dinamik", Jurnal Ilmu dan Inovasi Fisika, vol. 1, no. 02, 2017.

[14] S. Jamilatun dan M. Setyawan, "Pembuatan arang aktif dari tempurung kelapa dan aplikasinya untuk penjernihan asap cair," Spektrum Industri, vol. 12 , no. 1, p. 73-83, 2014.

[15] A. Apriyantono dan B. Kumara, "Identifikasi character impact odorants buah kawista (Feronia limonia)", Jurnal Teknolologi dan Industri Pangan, vol. XV, no.1, 2004.

[16] B. B. Rao, V. A. Raju dan G. S. Karuna, "Fabrication and mechanical behaviour of limonia acidissima ash - silicon carbide reinforced AL2024 alloy matrix hybrid composites", International Journal of Advance Research, Ideas and Innovation In Technology, vol. 4, no. 3, p. 1795-1802, 2018. 